\title{
OBITUARY
}

\section{Commandant Joseph Gaspard Hackin}

War has taken from us Joseph Hackin, a gallant gentleman and ripe scholar. He was by origin a Luxemburger, born at Boevange-surAttert in 1886. His brilliant career as a soldier began in 1914, when he joined the army of France as a private; he was mentioned in dispatches, and was raised in 1917 to the rank of lieutenant. In September 1939, now a captain in the reserve, he returned to the army, and in March 1940 he was given the charge of relations between the Eastern Mediterranean command and the French Legation in Afghanistan. When General de Gaulle raised his standard, Hackin at once joined him and devoted his full energies to the task of retrieving the honour of France. The Department of External Relations of the Free French Forces was placed under his charge. Unhappily he was not destined to fight the good fight long: enemy action early in 1941 put an end to his life of eager activity and high achievement. He was only 54 years of age. With him perished also his wife, who had shared his labours and taken a part with him in the great work of the French Archæological Mission in Afghanistan.

Hackin has earned a title to enduring honour by his services in the cause of Oriental archæology and art. He graduated with distinction in the University of Paris, becoming finally Docteur-ès-Lettres in 1916; and with Paris his whole future career was closely associated. He was placed on the staff of the Musée Guimet as Conservateur Adjoint in 1913, rising to the position of Acting Conservateur in 1923, and later becoming full Conservateur. One of his earliest literary works was La Peinture Chinoise au Musée Guimet, written by him and Chang Yi-chu and published in the Annales of the Museum for 1910. In 1911 appeared his L'Art Tibétain, a description of M. J. Bacot's collection on exhibition in the Museum; and in 1914 he contributed to M. V. Golubev's Peintures Bouddhiques aux Indes, which likewise formed part of the Museum's Annales. His volume, Les Scènes Figurées de la Vie du Bouddha d'après des Peintures Tibétaines, a fine and valuable study, appeared in 1916 as tome ii of the Mémoires concernant l'Asie Orientale published by the Académie des Inscriptions et Belles Lettres.

In 1922 began the great work with which Hackin's name will always be associated, the exploration of the ancient Buddhist sites 
in Afghanistan, accomplished with brilliant success by the Délégation Archéologique Française en Afghanistan, and the publication of the fruits of these labours, in all of which Hackin took an important part. He went thither on expeditions in 1924-5 and in 1929-1930, and was in 1934 promoted to the position of Director of the Délégation. $\mathrm{He}$ was joint author with the Godards of Volume II of the Delegation's Mémoires, namely Les Antiquités Bouddhiques de Bāmiyān, and sole author of Volume III, Nouvelles Recherches Archéologiques à Bāmiyān; in Volume VII, Recherches Archéologiques au Col de Khair Khaneh, he had as collaborator J. Carl. A luminous survey of these explorations betwen 1922 and 1932 is presented in his L'Euvre de la Délégation Archeologique Française en Afghanistan, of which the first part, Archéologie Bouddhique, was published at Tokyo in 1933 by the Maison Franco-Japonaise, an institution of which he was French Director from 1930. In 1923 the catalogues of his Museum received from him an important contribution, Les Collections Bouddhiques, and in the next year he published Formulaire Sanscrit-tibetain $d u x^{e}$ Siècle, an edition and translation of an ancient Buddhist text discovered by Professor Pelliot's Mission. The Influences of Indian art, published by our India Society in 1925, is a collection of essays by six scholars, of whom Hackin was one ; and in the First Term of the Session 1925-6 he delivered in our School three public lectures on "Les Monuments Bouddhiques et les Antiquités de l'Afghanistan ". The links that bound him to London were indeed close, for he was a member of the Royal Central Asian Society, the Royal Geographical Society, and the India Society, and a Fellow of the Royal Anthropological Society. He became in 1928 Professor of Indian Archæology and Art at the Ecole du Louvre, and in the same year was published a valuable contribution by him in a handsome de luxe volume, Mythologie Asiatique. His old Museum again in 1931 published a guide-book by him, this time La Sculpture Indienne et Tibétaine au Musée Guimet; and in 1936 the results of his visit to the sites of Bäzäklik and Murtuq in Chinese Turkestan were presented in his Recherches Archéologiques en Asie Centrale. This summary of his career is far from exhaustive, but from it the reader will be able to form some conception of the fullness and richness of the life which has been lost to us.

L. D. B. 